Special issue of the 3rd International Conference on Computational and Experimental Science and Engineering (ICCESEN 2016)

\title{
Utilization of Bigadiç Boron Works Waste Clay in Wall Tile Production
}

\author{
İ. ÖZKAN* \\ Dokuz Eylül University, TorbalıVocational School, Industrial Glass and Ceramics Department, \\ Torbalı, İzmir, Turkey
}

\begin{abstract}
The investigations on the use of the alternative raw materials have been always popular in the ceramic tile production. Manufacturers have been interested in this subject for both increasing product quality and decreasing production costs. In this research the Bigadiç boron works waste clay was utilized as an alternative raw material. Boron works waste clay was characterized by chemical and X-ray diffraction analyses. Ceramic characteristics were determined from pressed bodies, using four elevated firing temperatures $\left(1040,1060,1080\right.$, and $\left.1100^{\circ} \mathrm{C}\right)$ for samples with $5,10,15$, and $20 \mathrm{wt} \%$ boron works waste clay additions to a commercial wall-tile batch. The physical properties of the fired tiles were evaluated in terms of water absorption, linear shrinkage, and flexural strength. Microstructural observations were performed by scanning electron microscopy analyses. Based on the technological characteristics of the resulting ceramic material, the results were discussed.
\end{abstract}

DOI: 10.12693/APhysPolA.132.427

PACS/topics: waste clay, Bigadiç boron works, wall tile production, alternative raw material

\section{Introduction}

The growing consumption and the increase of industrial production cause exhaustion of the natural resources. On the other hand, industrial production wastes or sub-products are steadily growing and leading to environmental problems. Ceramic materials such as floor and wall tiles consist of clays with a very wide-ranging overall composition. Because of this, clay containing wastes in considerable percentages can be used to produce these materials [1--3]. In addition, studies on the utilization of waste materials and producing new products have gained great importance [4-8].

Turkey has about 800 million tons of boron reserves, which consist of $70 \%$ of the world boron reserves. The borate deposits of Turkey occur in western Anatolia, south of the Sea of Marmara, within an area roughly $300 \mathrm{~km}$ east-west by $150 \mathrm{~km}$ north-south. The main borate districts are Bigadiç, Kestelek, Sultançayır, Emet, and Kırka. The Bigadiç borate deposits are among the largest colemanite and ulexite deposits in the world. The high-grade colemanite and ulexite ores are adequate to supply the world's B needs for many years. During the processing of boron ores, concentrator wastes occur and these wastes are stored in tailing dams [9- 13$]$.

Ceramic wall tiles are highly porous ceramic materials. They are multicomponent systems that contain mainly clay, silica, feldspar, and carbonates [14-17] while approximately $50 \%$ of the wall tile body composition is composed of clay. Demand for clay in the ceramics industry has been growing steadily. Almost all of the clay extracted from the large deposits in the Sögüt and Istanbul

*e-mail: ilker.ozkan@deu.edu.tr regions of Turkey $(1,500,000$ ton/year) is used for wall tiles, floor tiles and sanitaryware by domestic industries. As a result, reserves of white-firing clays are running out. Thus, manufacturers are seeking alternative, less expensive raw materials [2].

The aim of this research is to characterize the Bigadiç waste clay (BWC) and to utilize BWC as a ceramic raw material in the wall-tile production. This study also will minimise the environmental impact of BWC disposal.

\section{Material and methods}

The waste clay investigated in this work was obtained from Eti Maden Bigadiç Boron Works, which is located in Balıkesir, Turkey. The waste clay was characterized by chemical and X-ray diffraction (XRD) analyses. The chemical composition of the waste clay was analyzed by atomic absorption spectroscopy (GBC). $\mathrm{B}_{2} \mathrm{O}_{3}$ component was determined by titrimetric method at Eti Maden laboratories. The phases present in the sample were identified by XRD using a Rigaku Model diffractometer with monochromatic $\mathrm{Cu} K_{\alpha}$ radiation.

Preparation and testing of the samples were done on a laboratory scale. Wall-tile compositions were formed using commercial raw materials (Istanbul and Sögüut clays, kaolinite, calcite, albite, and quartz), with BWC used in place of the Istanbul clay at varying proportions (Table I).

In order to enlighten the physical properties pellet samples were used. To produce pellet samples, each composition was dried and ground separately. The ground agglomerates were then humidified up to $6 \mathrm{wt} \%$ water. The humid powders were pressed under $150 \mathrm{~kg} / \mathrm{cm}^{2}$ pressure to obtain $100 \times 50 \times 6 \mathrm{~mm}^{3}$ prismatic samples. The shaped samples were dried at $120^{\circ} \mathrm{C}$ for $24 \mathrm{~h}$ and fired at $1040,1060,1080$, and $1100^{\circ} \mathrm{C}$ using a laboratory kiln (Nabertherm LH 15/14). Fired samples were used to 
TABLE I

Weight percent compositions of the wall-tile samples $\mathrm{R}_{i}$.

\begin{tabular}{l|c|c|c|c|c}
\hline \hline \multicolumn{1}{c|}{ Material } & R0 & R1 & R2 & R3 & R4 \\
\hline BWC & 0 & 5 & 10 & 15 & 20 \\
Istanbul clay & 20 & 15 & 10 & 5 & 0 \\
Sögüt clay & 30 & 30 & 30 & 30 & 30 \\
kaolinite & 15 & 15 & 15 & 15 & 15 \\
quartz & 15 & 15 & 15 & 15 & 15 \\
albite & 10 & 10 & 10 & 10 & 10 \\
calcite & 10 & 10 & 10 & 10 & 10
\end{tabular}

characterize the physical properties of the materials according to TS EN ISO 10545-3 and TS EN ISO 10545-4 norms $[18,19]$. The microstructures of the fired samples were analyzed by a scanning electron microscope, SEM (JEOL-JSM 6060). The colours of the fired bodies were analysed and classified in terms of the $L, a$, and $b$ parameters using a $3 \mathrm{NH} \mathrm{NH}-310$ model reflectance.

\section{Results and discussion}

Table 2 lists the chemical compositions of BWC. The main characteristic of the clay is its high $\mathrm{MgO}, \mathrm{CaO}$, and $\mathrm{B}_{2} \mathrm{O}_{3}$ content, and its low $\mathrm{Fe}_{2} \mathrm{O}_{3}$ content. XRD analysis showed that BWC powder sample contains ulexite, smectite, illite, quartz, calcite and magnesite phases (Fig. 1).

TABLE II

Chemical analysis results [wt\%] of the clay samples.

\begin{tabular}{c|c|c|c|c|c|c|c|c|c}
\hline \hline $\mathrm{SiO}_{2}$ & $\mathrm{Al}_{2} \mathrm{O}_{3}$ & $\mathrm{Fe}_{2} \mathrm{O}_{3}$ & $\mathrm{MgO}$ & $\mathrm{CaO}$ & $\mathrm{Na}_{2} \mathrm{O}$ & $\mathrm{K}_{2} \mathrm{O}$ & $\mathrm{TiO}_{2}$ & $\mathrm{~B}_{2} \mathrm{O}_{3}$ & $\mathrm{LOI}$ \\
\hline 29.05 & 2.63 & 0.26 & 14.57 & 17.16 & 1.02 & 0.12 & 0.03 & 9.61 & 25.20
\end{tabular}

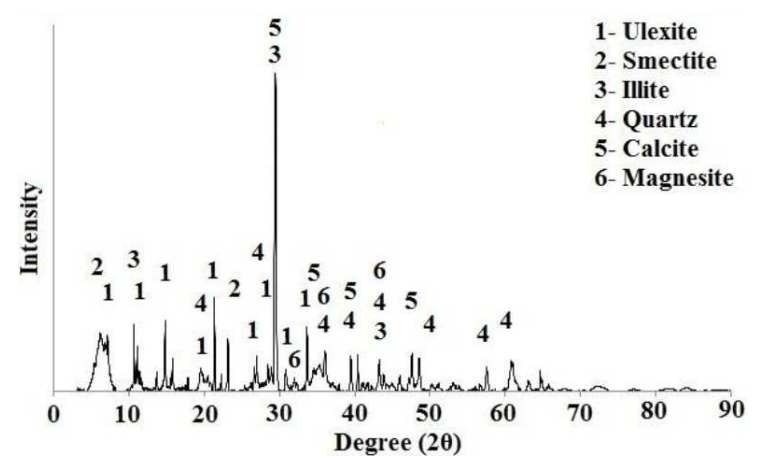

Fig. 1. XRD analysis of BWC powder.

A typical wall-tile composition (R0) and typical firing temperature $\left(1080^{\circ} \mathrm{C}\right)$ were selected for the tests. In this composition, we replaced Istanbul clay with BWC, and prepared tiles with various compositions (Table I). Tables III and IV list the water absorption and linear shrinkage values of the fired wall-tile bodies at different firing conditions, respectively.
TABLE III

Water absorption values of the prepared wall tile batches fired at different temperatures.

\begin{tabular}{c|c|c|c|c|c}
\hline \hline Temperature $\left[{ }^{\circ} \mathrm{C}\right]$ & R0 & R1 & R2 & R3 & R4 \\
\hline 1040 & 11.62 & 12.56 & 17.36 & 20.95 & 20.99 \\
1060 & 11.37 & 12.02 & 17.35 & 20.13 & 17.67 \\
1080 & 11.70 & 12.15 & 16.84 & 16.23 & 10.86 \\
1100 & 11.43 & 11.47 & 15.14 & 6.30 & 0.63
\end{tabular}

TABLE IV

Linear shrinkage values [\%] of the prepared wall tile batches fired at different temperatures.

\begin{tabular}{c|c|c|c|c|c}
\hline \hline Temperature $\left[{ }^{\circ} \mathrm{C}\right]$ & $\mathrm{R} 0$ & $\mathrm{R} 1$ & $\mathrm{R} 2$ & $\mathrm{R} 3$ & $\mathrm{R} 4$ \\
\hline 1040 & -0.23 & -0.06 & 0.23 & 1.00 & 1.37 \\
1060 & -0.17 & 0.18 & 0.43 & 0.89 & 0.03 \\
1080 & 0.29 & 0.11 & 0.43 & -0.49 & -3.49 \\
1100 & -0.03 & -0.17 & -0.23 & -4.77 & -8.46
\end{tabular}

The water absorption values tended to decrease with increasing temperature. For batches fired at a given temperature, water absorption values decreased with increasing BWC content. R1 composition showed optimum water absorption and contraction (according to $\mathrm{R} 0$ values) values that were obtained at a temperature $20^{\circ} \mathrm{C}$ below the typical firing temperature $\left(1080^{\circ} \mathrm{C}\right)$ of wall tiles, representing a saving in energy costs.

Cracks were observed for the samples having larger values than those for R1 composition. As a result, bending strength tests were performed for R 0 and R 1 bodies. The bending strengths of the bodies increased with increasing firing temperature (Table V). At a typical firing temperature of $1080^{\circ} \mathrm{C}, \mathrm{R} 0$ had strength of $18.9 \mathrm{MPa}$; R1 reached a similar value at $1060^{\circ} \mathrm{C}$.

TABLE V

Bending strength values for the selected wall-tile batches.

\begin{tabular}{c|c|c}
\hline \hline Temperature $\left[{ }^{\circ} \mathrm{C}\right]$ & $\mathrm{R} 0[\mathrm{MPa}]$ & $\mathrm{R} 1[\mathrm{MPa}]$ \\
\hline 1040 & 15.8 & 16.1 \\
1060 & 16.4 & 18.3 \\
1080 & 18.9 & 19.9 \\
1100 & 21.4 & 21.7
\end{tabular}

Colour measurements along the chromatic coordinates show that $L$ values increased while $a$ and $b$ values decreased with increasing temperature and BWC content ( $L$ value indicates the lightness scale where 0 is black; 100 is white, $a$ value indicates the red-green scale where positive values are red; negative values are green and 0 is neutral, $b$ value indicates the blue yellow scale where positive values are yellow; negative values are blue and 0 is neutral). It is reasonable to think that high $\mathrm{CaO}$ content caused whitening effect. As a result $L$ values increased with increasing BWC content and temperature.

Figures 2 and 3 show the microstructures of the ceramic bodies fired at elevated temperatures. The SEM 

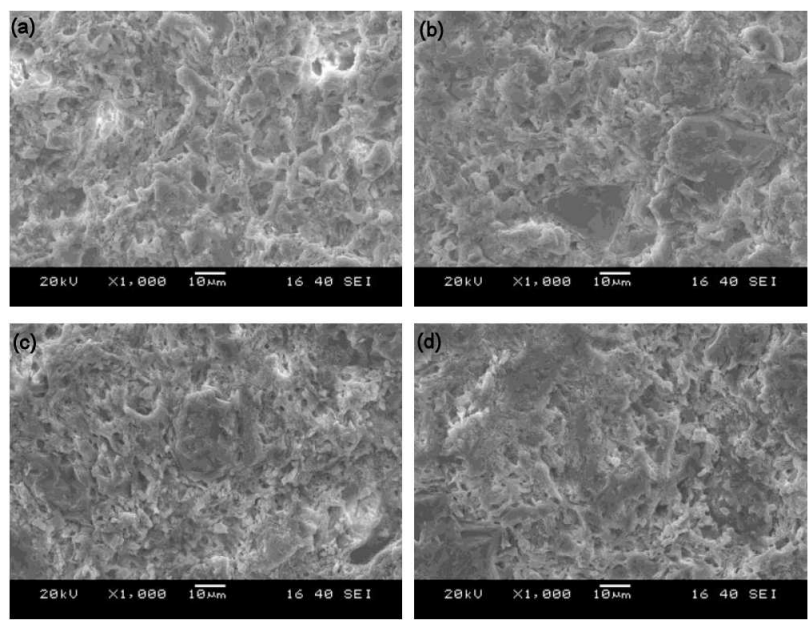

Fig. 2. SEM images of RO samples fired at (a) $1040{ }^{\circ} \mathrm{C}$, (b) $1060{ }^{\circ} \mathrm{C}$, (c) $1080^{\circ} \mathrm{C}$, (d) $1100^{\circ} \mathrm{C}$.
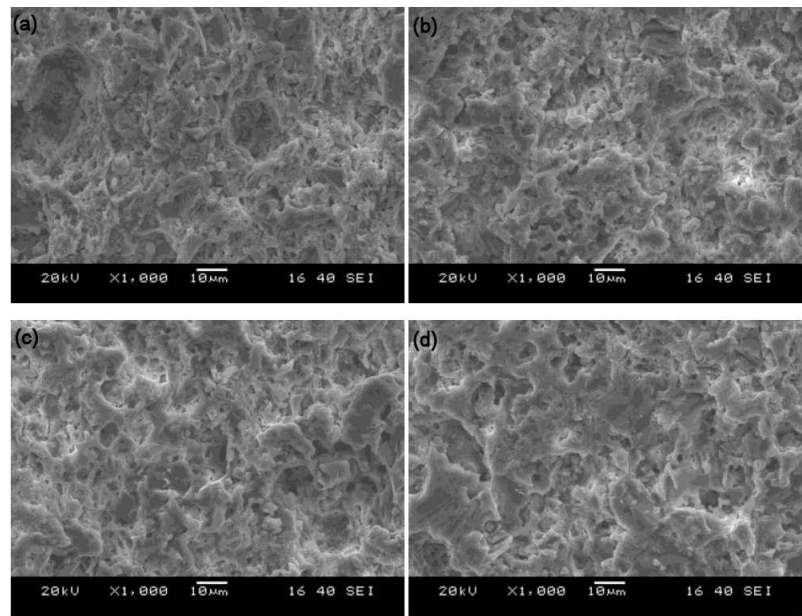

Fig. 3. SEM images of R1 samples fired at (a) $1040^{\circ} \mathrm{C}$, (b) $1060{ }^{\circ} \mathrm{C}$, (c) $1080{ }^{\circ} \mathrm{C}$, (d) $1100{ }^{\circ} \mathrm{C}$.

images show the progression of densification with increasing firing temperatures. The particles tend to approach and the porosity reduces as the temperature increase. It is reasonable to think that microstructures of $\mathrm{R} 0$ and R1 samples fired at same temperatures show similarities. This result is also compatible with the physical test results.

\section{Conclusions}

In this study, the characteristics of BWC and its usage in wall-tile production were investigated. From the results obtained, the following conclusions can be drawn.

The predominant oxides in $\mathrm{BWC}$ are $\mathrm{SiO}_{2}, \mathrm{MgO}, \mathrm{CaO}$ and $\mathrm{B}_{2} \mathrm{O}_{3}$. Ulexite, smectite, illite, quartz, calcite, and magnesite are found as the main phases. The results showed that it was possible to use $5 \mathrm{wt} \%$ BWC to produce wall-tile ceramics. It was observed that R1 batch that was fired at $1060{ }^{\circ} \mathrm{C}$ and $\mathrm{R} 0$ that was fired at $1080^{\circ} \mathrm{C}$ (the typical firing temperature) had similar physical properties. This result was taken as an indication of cost decrease for a firing energy. The results of colour measurements showed that $\mathrm{R} 1$ showed higher colour values than $\mathrm{R} 0$ due to $\mathrm{CaO}$ content of BWC. SEM micrographs, taken at increasing firing temperatures, show the reduction of porosity and the progression of enhanced densification with increasing temperature. It is expected that this study will help to improve the knowledge about BWC and contribute correct assessment of the deposits.

\section{Acknowledgments}

This work was supported by the Dokuz Eylül University Scientific Research Project within the project number 2015.KB.FEN.027.

\section{References}

[1] I. Demir, M. Orhan, Build. Environm. 38, 1451 (2003).

[2] I. Özkan, M. Çolak, R.E. Oyman, Appl. Clay Sci. 49, 420 (2010).

[3] I. Özkan, Z. Yayla, Ceram. Techn. 34, 32 (2012).

[4] F. Yılmaz, H.A. Kamiloğlu, E. Sadoğlu, Acta Phys. Pol. A 128, B-392 (2015).

[5] S. Kılınçarslan, Acta Phys. Pol. A 128, B-469 (2015).

[6] A. Sezer, A. Mardani-Aghabağlou, A. Boz, N. Tanrinıan, Acta Phys. Pol. A 130, 23 (2016).

[7] M. Arıcı, B. Yılmaz, H. Karabay, Acta Phys. Pol. A 130, 266 (2016).

[8] S. Özavc1, B. Çetin, Acta Phys. Pol. A 130, 316 (2016).

[9] B. Oto, A. Gür, Ann. Nucl. Energy 59, 72 (2013).

[10] Ü. Gemici, G. Tarcan, C. Helvacı, A.M. Somay, Appl. Geochem. 23, 2462 (2008).

[11] C. Helvacı, H. Mordogan, M. Çolak, İ. Gündoğan, Int. Geol. Rev. 46, 177 (2004).

[12] C. Helvac1, Econom. Geol. 90, 1237 (1995).

[13] C. Helvacı, R.N. Alonso, Turk. J. Earth Sci. 9, 1 (2000).

[14] M. Tarhan, B. Tarhan, T. Aydın, Ceram. Int. 42, 17110 (2016).

[15] H. Elçi, J. Clean. Prod. 112, 742 (2016).

[16] S.J.G. Sousa, J.N.F. Holanda, Ceram. Int. 31, 215 (2005).

[17] J.L. Amorós, M.J. Orts, S. Mestre, J. Garcia-Ten, C. Feliu, J. Europ. Ceram. Soc. 30, 17 (2010).

[18] TS EN ISO 10545-3. Ceramic Tiles - Part 3: Determination of Water Absorption, Apparent Porosity, Apparent Relative Density and Bulk Density, 2000.

[19] TS EN ISO 10545-4. Ceramic Tiles - Part 4: Determination of Modulus of Rupture and Breaking Strength, 2000. 